\title{
Blood-Testis Barrier and Sperm Delayed in the Cauda Epididymis of the Reproductively Regressed Syrian Hamsters
}

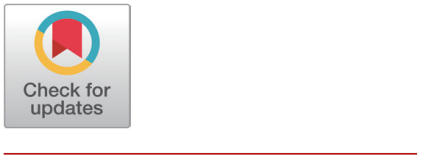

Received: February 10, 2021

Revised: February 24, 2021

Accepted: February 28, 2021

${ }^{+}$Corresponding author

Donchan Choi

Dept. of Life Science, College of Public

Health and Welfare Sciences, Yong-In

University, Yonginsi 17092, Korea.

Tel: +82-31-8020-2781

Fax: +82-31-8020-2886

E-mail:dcchoi@yongin.ac.kr

Copyright @ 2021 The Korean Society of Developmental Biology.

This is an Open Access article distributed under the terms of the Creative Commons Attribution Non-Commercial License (http://creativecommons.org/licenses/ by-nc/4.0/) which permits unrestricted non-commercial use, distribution, and reproduction in any medium, provided the original work is properly cited.

\section{ORCID}

Geon Hyung Jeon

https://orcid.org/0000-0001-6267-1537

Sung-Ho Lee

https://orcid.org/0000-0003-2866-3642

Yong-Pil Cheon

https://orcid.org/0000-0002-8497-9257

Donchan Choi

https://orcid.org/0000-0002-5170-090X

Conflict of interests

The authors declare no potential conflict of interest.

\section{Acknowledgements}

This research was supported by Basic Science Research Program through the National Research Foundation of Korea (NRF) funded by the Ministry of Education (2017R1D1A1B03028581).

\author{
Geon Hyung Jeon', Sung-Ho Lee ${ }^{2}$, Yong-Pil Cheon ${ }^{3}$, and ${ }^{\dagger}$ Donchan Choi ${ }^{1}$ \\ 'Dept. of Life Science, College of Public Health and Welfare Sciences, Yong-In University, Yongin 17092, Korea \\ ${ }^{2}$ Dept. of Biotechnology, Sangmyung University, Seoul 03016, Korea \\ ${ }^{3}$ Division of Developmental Biology and Physiology, Dept. of Biotechnology, Sungshin University, Seoul 02844, Korea
}

\begin{abstract}
The Syrian (golden) hamsters are seasonal breeders whose reproductive functions are active in summer and inactive in winter. In experimental facility mimicking winter climate, short photoperiod (SP) induces gonadal regression. The blood-testis barrier (BTB) of the sexually involuted animals have been reported to be permeable, allowing developing germ cells to be engulfed or sloughed off the epithelium of the seminiferous tubules. The expressions of genes related to the tight junction composing of BTB were investigated in the reproductive active and inactive testes. Claudin-11, occludin, and junctional adhesion molecule (JAM) were definitely expressed in the active testes but not discernably detected in the inactive testes. And spermatozoa (sperm) were observed in the whole lengths of epididymides in the active testes. They were witnessed in only cauda region of the epididymides but not in caput and corpus regions in animals with the inactive testes. The results imply that the disorganization of BTB is associated with the testicular regression. The developing germ cells are swallowed into the Sertoli cells or travel into the lumen, as supported by the presence of the sperm delayed in the last region of the epididymis. These outcomes suggest that both apoptosis and desquamation are the processes that eliminate the germ cells during the regressing stage in the Syrian hamsters.
\end{abstract}

Keywords: Photoperiod, Blood-testis barrier, Reproductive activity, Male Syrian hamster

\section{INTRODUCTION}

Spermatogenesis is the dynamic process by which spermatozoa (sperm) are produced from spermatogonium cells in the seminiferous tubules of the testis. This process starts with the mitotic division of the spermatogonial stem cells located close to the basement membrane of the seminiferous tubules (de Kretser et al., 1998). The spermatogonial stem cells produce two types of cells, type A and type B cells. The former replenishes the stem cells and the latter differentiates into primary spermatocytes. The primary spermatocyte divides twice meiotically to generate four spermatids. The spermatids are transformed into free sperm by the differentiation of spermiogenesis. 
Authors' contributions

Conceptualization: Lee SH, Cheon YP, Choi D.

Data curation: Jeon $\mathrm{GH}$.

Formal analysis: Jeon $\mathrm{GH}$, Choi D.

Methodology: Jeon GH, Choi D.

Software: Jeon GH, Choi D.

Validation: Lee SH, Cheon YP, Choi D.

Investigation: Jeon $\mathrm{GH}$.

Writing-original draft: Choi D.

Writing-review \& editing: Jeon GH, Lee SH, Cheon YP.

\section{Ethics approval}

This study was approved by Yong-In University Institutional Animal Care and Use Committee (YUIACUC-2020-02)
During these courses of germ cells generation, the notably primary spermatocytes must pass through between the Sertoli cells in the epithelial layer of the seminiferous tubules (Mruk \& Cheng, 2015; Hollenbach et al., 2018). The Sertoli cells are associated with each other by cell junctions, named the blood-testis barrier (BTB) including tight junctions, basal ectoplasmic specialization (ES), and gap junction. The connections imply Sertoli-Sertoli and Sertoli-germ cell interactions at the cell junctions. The BTB prevents water, electrolytes, ions, and biomolecules from traversing paracellular space and provides an immune privilege to the meiotic and post-meiotic germ cell. And the BTB separates the germinative epithelial layer into the basal and the adluminal compartment. The germ cells are immotile cells, and they move passively according to the passage situations, undergoing repeatedly locking and unlocking of the structures on the surface of Sertoli cells to enable for the germ cells to move. Post-meiotic germ cell development is taken place in the adluminal part and results in production of free and independent sperm.

On the other hand, many small mammals inhabiting in temperate zone present a characteristic of seasonal breeding. They show a cyclic alteration of active and inactive spermatogenesis (Choi \& Lee 2012). Their spermatogenesis is arrested in the winter season due to the shortened length of day time called short photoperiod (SP). And animals are unable to breed for several months (Young et al., 1999; Young et al., 2001; Luaces et al., 2013, 2014). The seminiferous tubules of the regressed testis contain only Sertoli and spermatogonial cells, displaying complete absence of meiosis process. Contrarily in others of the seasonal breeders, spermatogenesis is partially sustained in the inactive testes, and some meiotic activity is remained (Andersen Berg et al., 2001; Morales et al., 2002; Morales et al., 2007; Dadhich et al., 2010, 2013). The seminiferous tubules of the regressed testis contain Sertoli, spermatogonial cells, and a few spermatocytes, implying a subsistence of meiosis.

In the active testes, the BTB is tightly regulated and involved in the rapid reorganization of junction-associated molecules. In the inactive testes, the BTB has been shown to become permeable, leading the molecules to reach the adluminal compartment of the seminiferous epithelium (Jiménez et al., 2015). This alteration of functionality is related to the rearrangement of cell adhesion proteins composed of the tight junctions. The findings triggered to investigate the expressions of genes forming cell junction in reproductively active and inactive testes of Syrian hamsters.

Three molecules consisting of BTB were attracted for this investigation. Claudin-11 was selected among various claudins because its knockout mice resulted in sterile due to loss of tight junction integrity in mice (Morita et al., 1999; Mazaud Guittot et al., 2010; Pan et al., 2018). Moreover, other members of claudin were reported to be involved in the reorganization of the tight junction (Meng et al., 2005; Morrow et al., 2009; Smith \& Braun, 2012). And in occludin knockout mice, the testes became sterile at late period of life time despite of normal histological view at six weeks of age (Saitou et al., 2000). Junctional adhesion molecules (JAMs) have been presented at the Sertoli cell tight junctions, indicating the involvement in Sertoli cell-germ cell communication (Gliki et al., 2004).

Therefore, the goal of the present work was to show the expressions of the genes related to cell junctions of BTB in testes of the Syrian hamsters whose reproductive activities were active or inactive. The full length of epididymides were traced whether there were some germ cells including free sperm.

\section{MATERIALS AND METHODS}

\section{Experimental animals and photoperiod treatment}

Mature male Syrian hamsters (Mesocricetus auratus) as a photoperiodic breeding mammal were used in this investigation. They were housed in animal breeding boxes inside the animal breeding 
room those were manufactured with plywood and the lighting scheme was regulated by the plug-in timer. Ventilation was furnished with the small fans in one side and the outer lighting was blocked completely by using curved black sheets. The animals were fed with standard laboratory mouse chow and tap water ad libitum. Sanitary conditions were managed repeatedly. The long photoperiod (LP) was set by lights of 14 hours and darkness of 10 hours and the LP lights of 10 hours and darkness of 14 hours. The animal breeding boxes were lined side by side. The lighting of animal breeding room was adjusted to identical to the SP lighting scheme and the middle time in day time of each photoperiod was synchronized and checked daily in the ambient temperature of $22 \pm 1^{\circ} \mathrm{C}$. The condition of management of animals was approved by the Yongin University Institutional Animal Care and Use Committee (YUIACUC-2020-02).

The animals were arranged into two groups: animals kept in LP or SP lighting condition. They were housed in each photoperiod for 8 full weeks.

\section{Determination of body and testes weights}

The hamsters' body weights were weighed at two weeks intervals. The testicular volume was measured by laparotomy at 0,4 , and 8 weeks. The animals were anesthetized with Zoletil 50 (Virbac, Carros, France), if necessary, with the aid of diethyl ether. Following the excising the skin overlying the scrotal sac and protruding the testicles within the scrotal sac, the major axis and the minor axis of the testicles were immediately measured by vernier calipers (series 530, Mitutoyo America, Boulevard Aurora, IL, USA). The skin excised was sutured with autoclips (CLAY ADAMS ${ }^{\circledR}$ brand, MikRon Precision, Monroe, CT, USA). At the end of the experiment, after the determination of the testicular mass as mentioned above, the animals were decapitated and the various internal organs, including the reproductive accessory organs, were isolated and directly weighed. The testicles and epididymides were kept in formalin until use for histological examination.

The measured values of the testicles were converted into testicular mass by calculating the major axis and the minor axis via a converting equation formulated previously (Watson-Whitmyre \& Stetson, 1985). The calculated masses of testicles were compared, plotted, and analyzed with the testicular weights those were directly weighed.

\section{Gene expressions in testes}

The expressions of genes related to the structure of BTB were examined in the testes of two reproductively active and inactive Syrian hamsters those were prepared by regulating the photoperiod. The genes were claudin-11, occludin, and JAM.

\section{Primers}

The primer sequences used in the present investigation were selected from the reports provided by the GenBank and the National Center for Biotechnology Information. Table 1 shows the primers chosen. Glyceraldehydes-3-phosphate dehydrogenase (GAPDH) was used as reference standard for RT-PCRs in this study. Sequences were determined by a commercial sequencing service company (Bioneer, Danjeon, Korea).

\section{Total RNA extraction}

Testicular tissues were subjected to the total RNA extractions by using TRIzol ${ }^{\circledR}$ Reagent (Invitrogen, Carlsbad, CA, USA) according to the manufacturer's protocol. A part of testicular tissue (50-100 mg) was excised and sonicated (VCX130, Vibra CellTM, Sonics \& Materials, Newtown, CT, USA) with $1 \mathrm{~mL}$ of TRIzol ${ }^{\circledR}$ Reagent. The samples were moved into new microcentrifuge tubes and spun at 12,000 rpm for $5 \mathrm{~min}$ at $4^{\circ} \mathrm{C}$. The supernatant was transferred into the new tubes and 
Table 1. Primer sequences used for RT-PCR

\begin{tabular}{|c|c|c|c|}
\hline Gene & Primer sequence (5'- 3') & Length (bp) & Reference \\
\hline \multirow[t]{2}{*}{ Claudin-11 } & F - ACCAATGACTGGGTGGTGAC & 496 & XM_0211226939.1 \\
\hline & R - AATAGAAACGGTTTTCTCCA & & \\
\hline \multirow[t]{2}{*}{ Occludin } & F - CCAATCATTATGCACCAAGC & 681 & HQ174780.1 ${ }^{2)}$ \\
\hline & R - CAATGGCTATAGCCTCCTGG & & \\
\hline \multirow[t]{2}{*}{ JAM } & F - GGTACAAGGCAAGGGTTCGG & 519 & EU856104.1 $1^{2)}$ \\
\hline & R - TCCCCCGACTTTGGATCAA & & \\
\hline \multirow[t]{2}{*}{ GAPDH } & F - AAATGACCCCTTCATTGACC & 420 & DQ403055.1 $1^{2)}$ \\
\hline & R - CCTTCCACAATGCCAAAGTT & & \\
\hline
\end{tabular}

${ }^{1)} \mathrm{NCBI}$ (National Center for Biotechnology Information) Reference Sequence.

${ }^{2)}$ GenBank.

RT-PCR, reverse transcription-polymerase chain reaction; bp, base pair; JAM, junction adhesion molecule; GAPDH, glyceraldehyde 3-phosphate dehydrogenase; $F$, forward; $R$, reverse.

kept at room temperature for 5 min of incubation, permitting entire dissociation of the nucleoprotein complex. The tubes had $0.2 \mathrm{~mL}$ of chloroform and were capped securely. After the incubation of 2-3 $\mathrm{min}$, the tubes were spun at $12,000 \mathrm{rpm}$ for $15 \mathrm{~min}$ at $4^{\circ} \mathrm{C}$. The upper aqueous phase was relocated to the new tubes. $0.5 \mathrm{~mL}$ of isopropanol was added and left at room temperature for $10 \mathrm{~min}$. Then the tubes were rotated 12,000 rpm for $10 \mathrm{~min}$ at $4^{\circ} \mathrm{C}$ (Sartorius, Centrisart A-14C, Gottingen, Germany). The supernatant was removed and the pellets were resolved in $1 \mathrm{~mL}$ of $75 \%$ ethyl alcohol. Following agitation, the samples were rotated at 7,500 rpm for $5 \mathrm{~min}$ at $4^{\circ} \mathrm{C}$. The supernatant was removed and the pellets were dried for at least $5 \mathrm{~min}$. The pellet was resolved with 20-50 $\mu \mathrm{L}$ of RNase-free water.

\section{Reverse transcription-polymerase chain reaction (RT-PCR)}

The extracted total RNAs were applied to RT-PCR reactions. According to the manufacturer's instructions the reactions were carried out with Maxime ${ }^{\mathrm{TM}} \mathrm{RT}$ PreMix and AccuPower PCR Premix (Bioneer). Reverse transcription was initially performed to create complementary cDNAs representing tissue-specific RNA populations. An appropriate amount of tRNA was transferred to new microcentrifuge tubes and blended with the following materials: reverse transcription reaction buffer, dNTPS (dATP, dCTP, dGTP, dTTP), oligo (dT) 20 primer, RNase inhibitor, reverse transcriptase, and DEPC-treated water. The tubes were gently shaken and incubated at $42{ }^{\circ} \mathrm{C}$ for at least $60 \mathrm{~min}$. The tubes were heated to $85^{\circ} \mathrm{C}$ for $5 \mathrm{~min}$ to inactivate the reverse transcriptase. The products were stored at $-20^{\circ} \mathrm{C}$.

PCR was executed with the cDNA products diluted with TE buffer $(10 \mathrm{mM}$ Tris [pH 8.0] and $0.1 \mathrm{mM}$ EDTA). The microcentrifuge tubes with template cDNA (usually $10 \mathrm{ng}$ ) were mixed with 10× PCR Buffer, primers (forward and reverse), dNTP Mix, Taq DNA Polymerase, 25 $\mathrm{mM} \mathrm{MgCl}$, and water. The tubes were shaken gently by mixing and spun shortly to fall down all components to the bottom of the tubes. The 40 cycles of PCR were run with the followings in the order: denaturing at $94^{\circ} \mathrm{C}$ for 20 seconds, annealing at $55^{\circ} \mathrm{C}$ for 30 seconds, and extension at $72^{\circ} \mathrm{C}$ for $1 \mathrm{~min}$. The final synthesis stage was performed at $72^{\circ} \mathrm{C}$ for $5 \mathrm{~min}$ and then cooled down to $4^{\circ} \mathrm{C}$.

The products were analyzed by using gel electrophoresis in $1.0 \%$ agarose gel (100 V, $60 \mathrm{~min})$ and visualized by ethidium bromide. The bands were recognized using the image analysis system (Chemi Doc XRS, Bio-Rad, Hercules, CA, USA).

\section{Elution and sequence determination}

The PCR products were identified and purified through the agarose gel electrophoresis 
according to the manufacturer (AccuPrep ${ }^{\circledR}$ PCR/Gel Purification Kit, Bioneer). The visualized gel bands were sliced off using disinfected blade. The gel pieces were mixed with 3 volumes of FB buffer. The clean tubes with the gel pieces were incubated at $50^{\circ} \mathrm{C}$ for 10 min with mixing by inverting the tubes at the intervals of $2 \mathrm{~min}$. Same amount of absolute isopropanol was added and mixed immediately by repeating upside down. The mixture was relocated to a binding column equipped with a $2 \mathrm{~mL}$ collection tube. The cap was closed and spun at 14,000 rpm for $1 \mathrm{~min}$. The binding column was rebuilt with collection tube after discarding the flow-through fluid. $500 \mu \mathrm{L}$ of W2 buffer was poured and spun at 14,000 rpm for $1 \mathrm{~min}$. The binding column was rebuilt as mentioned above. Then the stage with W2 buffer was repeated again and spun at 14,000 rpm for 1 min. The binding column tube was transferred to a clean $1.5 \mathrm{~mL}$ microcentrifuge tube for elution. $30 \mu \mathrm{L}$ of EA buffer was added cautiously onto the binding column tube and left for at least $1 \mathrm{~min}$ at room temperature. Finally, the new tube was spun at 14,000 rpm for $1 \mathrm{~min}$. The eluant was sent to Bioneer for analyzing the sequence of the genes.

\section{Histological examination}

The paraffin tissue section was applied for the histological examinations of testicles and epididymides. The tissues were fixed in formalin for the time being. The fixed tissues were dehydrated using a series of increasing concentrations of ethanol (70\%, 80\%, 90\%, 95\%, and 100\%) for 1.5 hours with mild shaking and immersed in absolute ethanol overnight. The tissues were submerged in xylene three times for 30 minutes and in paraffin at $56^{\circ} \mathrm{C}$ three times for 30 minutes. Then they were embedded in paraffin and sliced at the width of $5 \mu \mathrm{m}$. The slices were mounted on slide glasses and the slides were subjected to hematoxylin (Sigma-Aldrich, St. Louis, MO, USA) and eosin (Sigma-Aldrich) staining solutions for 5 minutes, respectively. They were left for a while to evaporate in the air and treated with Canada balsam (Duksan Pure Chemicals, Ansan, Korea) for permanent specimen, and observed under microscope (DM500, Leica, Wetzlar, Germany).

\section{Statistical analysis}

Data were expressed as mean $\pm \mathrm{SD}$. The student's $t$-test was utilized for statistical analysis. Significant differences were considered at $p<0.05$.

\section{RESULTS}

\section{Changes of body weight}

The body weights of Syrian hamsters were not altered unexpectedly by photoperiod, harmonizing with normal growth pattern as reported in the similar experiment performed previously (Jeon et al., 2020). The animals housed in SP for 8 weeks became a little sensitive to the touching. But there was no any particular aberrant action in any animals housed in each photoperiod.

\section{Changes of various organs}

\section{1) Final weights of testes, epididymides, and seminal vesicles}

The real weights of reproductive organs, including testicles, epididymides, and seminal vesicles, were actually weighed at the end of this experiment (Fig. 1). The testicles of animals housed in LP were massive and big but those in SP light and very diminutive. A significant difference of testicular weights in the animals of LP and SP conditions $(p<0.05)$ was found. Likely the results of testicular weights, the weights of the epididymis and the seminal vesicle in the SP animals were significantly 

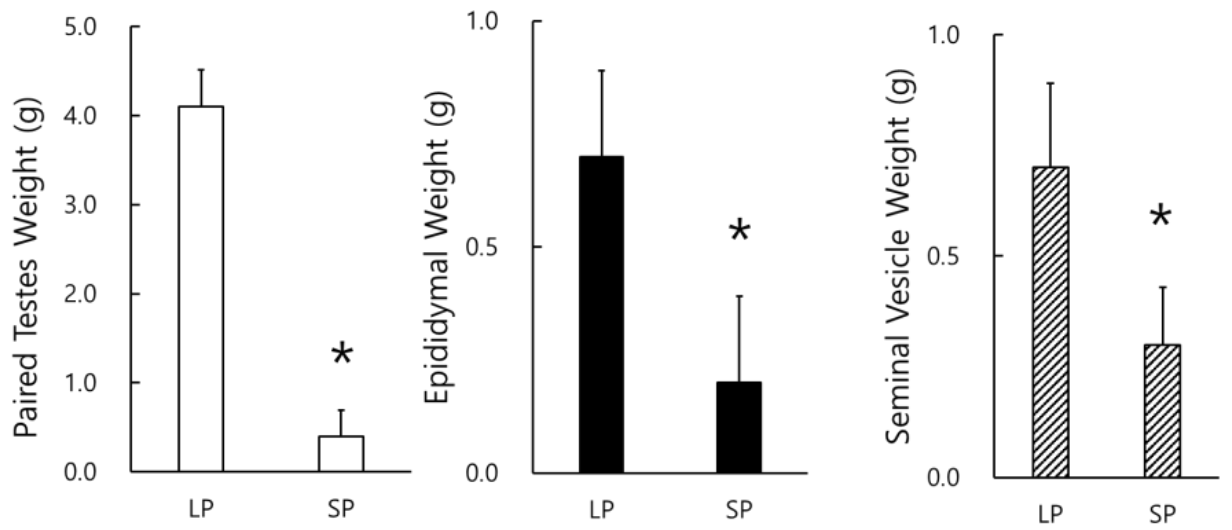

\section{Photoperiod}

Fig. 1. Changes of actual weights of testes, epididymides, and seminal vesicles in Syrian hamster at the end of experiment. Note that SP animals showed completely regressed testes, epididymides, and seminal vesicles. * indicates statistical significance $(p<0.05)$. LP, long photoperiod; SP, short photoperiod $(n=6)$.

different to those in LP animals $(p<0.05)$. All the animals housed in SP presented apparently miniatured reproductive accessory organs.

\section{2) Average changes of testicular masses with time}

By using the values of the major axis and the minor axis of the testicles, the testicular masses were calculated and were employed on behalf of the actual testicular weights (Watson-Whitmyre \& Stetson, 1985). Fig. 2 shows the average changes of testicular mass of hamsters. At the beginning of this experiment all animals had the large and active testes. they also showed relatively large testicles at the 4th week, although the testes became a little diminutive, still sustaining the functional spermatogenesis. At the 8th week the average masses of testicles of SP animals became quite small and were significantly different from those of LP animals $(p<0.05)$.

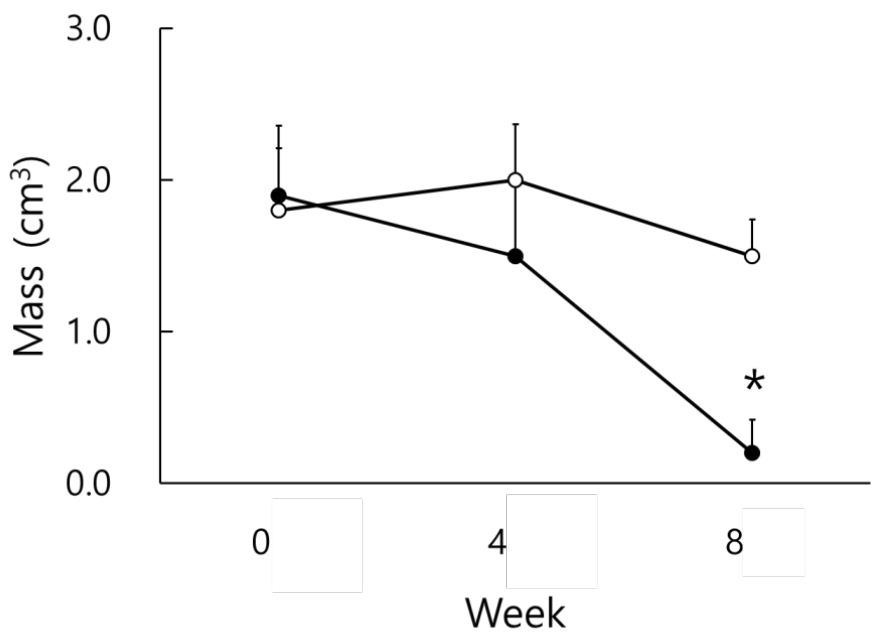

Fig. 2. Changes of testicular mass of Syrian hamster. The testicular masses of Syrian hamsters were gauged at 4 weeks intervals. ${ }^{*}$ indicates statistical significance $(p<0.05)$. LP, long photoperiod; SP, short photoperiod. 


\section{3) Individual changes of testicular mass with time}

Fig. 3 indicates the testicular masses of individual animals in each group. There were apparent individual differences in groups at the end of the present investigation. Each animal in LP group had large testes all the time (Fig. 3, LP) and that in SP group displayed very small testicles (Fig. 3, $\mathrm{SP}$ ), demonstrating reproductive active and inactive testes, respectively. If the presence and absence of spermatozoa in the testicles is regarded by histological examination as a standard to distinguish gonadal involution, SP animals present entire involution of testis.

\section{4) Testicular masses calculated versus testicular weights weighed}

The testicular masses determined by computing from the axes and the actual testicular weights weighed by direct weighing at the end of experiment were compared to scrutinize the mutual correlation between mass and weight. As the correlation coefficient resulted in near to $1\left(\mathrm{R}^{2}=0.91\right)$, it could be evaluated that the values converted from the measures exhibited the values weighed literally as reported previously (Lee et al., 2013; Jeon et al., 2020). The findings imply that the values calculated could completely replace substantially the values weighed directly.

\section{5) Weights of various organs at the end of experiment}

Various organs were isolated and weighed to inspect any weighable alterations of internal organs at the end of experiment (Table 2). The weights of the other organs that were unrelated to the reproductive functions were not discernibly modified by the photoperiod.

\section{Expressions of BTB genes in reproductively active and inactive testes}

The male Syrian hamsters housed in LP for 8 weeks resulted in the large testes that was nearly $2.05 \mathrm{~g}$ of average individually, which represents full spermatogenic activities. The expressions of BTB genes were primarily detected by RT-PCR in the Syrian hamsters housed in LP (Fig. 4). The claudin, occludin, and JAM genes were obviously expressed in the animals. The animals housed in SP for 8 weeks showed very diminutive testes that was $0.20 \mathrm{~g}$ of average of each testis, which represents a complete arrest of spermatogenesis. In the sexually regressed and small testes, claudin was weakly expressed. On the other hand, occludin and JAM genes were not observed at all. GAPDH was used as reference standard for RT-PCRs.
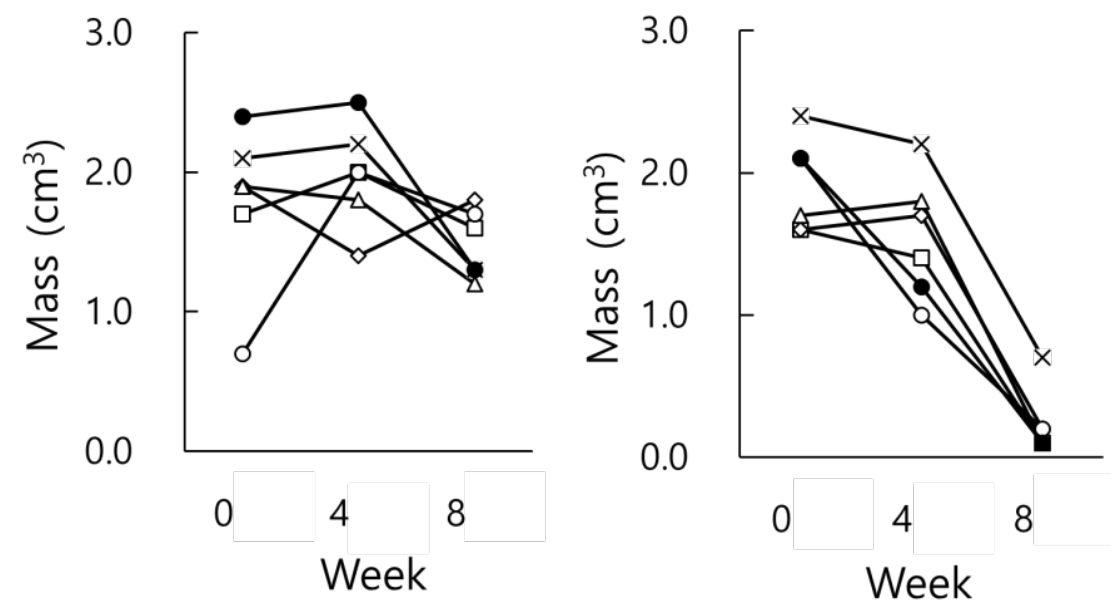

Fig. 3. Changes of testicular mass in individual animals. LP, long photoperiod; SP, short photoperiod. 
Table 2. Changes in weights of various organs

\begin{tabular}{ccc}
\hline \hline Variable & LP & SP \\
\hline Heart $(\mathrm{g})$ & $0.7 \pm 0.16$ & $0.8 \pm 0.14$ \\
Lung $(\mathrm{g})$ & $0.9 \pm 0.11$ & $0.8 \pm 0.09$ \\
Liver $(\mathrm{g})$ & $4.9 \pm 0.68$ & $4.4 \pm 0.75$ \\
Spleen $(\mathrm{g})$ & $0.2 \pm 0.04$ & $0.2 \pm 0.05$ \\
Kidney $(\mathrm{g})$ & $1.4 \pm 0.2$ & $1.2 \pm 0.13$ \\
\hline
\end{tabular}

Data are represented as the mean $\pm \mathrm{SD}(\mathrm{n}=6)$.

LP, long photoperiod; SP, short photoperiod.

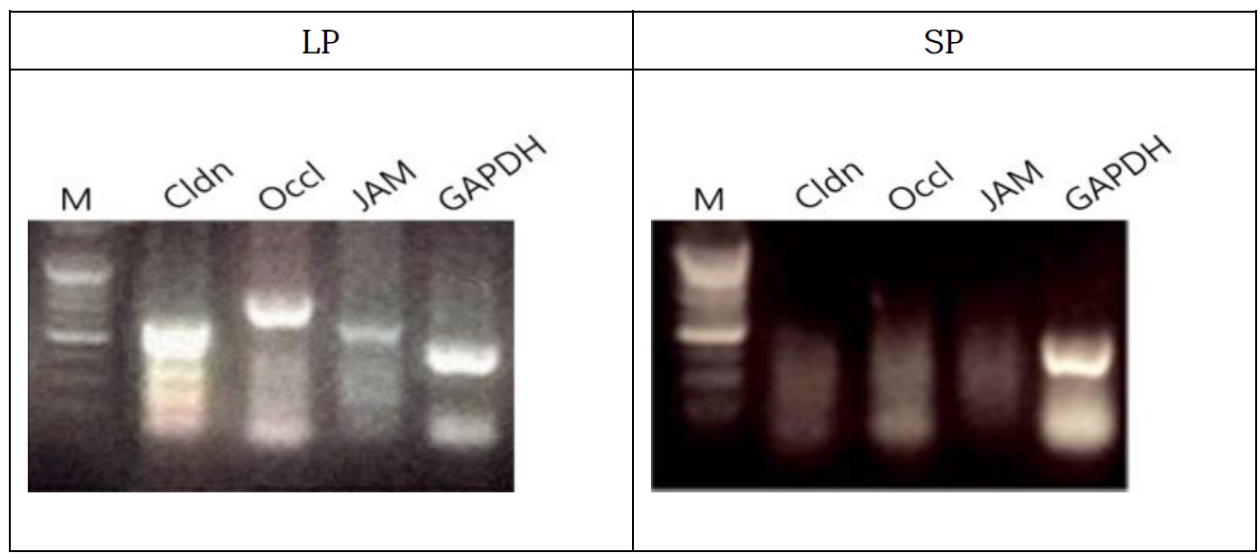

Fig. 4. Representative RT-PCR results of claudin-11, occludin, and JAM genes. RT-PCRs were performed in testes of Syrian hamsters housed in each photoperiod. LP, long photoperiod; SP, short photoperiod; M, 100 bp marker; Cldn, claudin-11; Occl, occludin; JAM, junction adhesion molecule; GAPDH glyceraldehydes-3-phosphate dehydrogenase.

\section{Histological examination of testes}

The testicles were categorized into reproductively active and inactive ones (Fig. 5). The active testicles and the inactive ones were shown in all animals of each photoperiod of LP and SP, respectively.

The active testicles showed all stages of germ cells, including spermatogonia, spermatocytes, spermatids, and spermatozoa. These results were apparent in the spacious diameter of the seminiferous tubules. The average diameter of the tubules of active testicles was near $280 \mu \mathrm{m}$. The lumen of the seminiferous tubules was full of spermatozoa with tails similar to a sort of wave-like pattern. Contrarily the inactive testicles displayed little germ cells in the epithelium of the seminiferous tubules. SP animals showed primarily spermatogonia and some spermatocytes, without any spermatids and sperm with tail, in the seminiferous tubules. The diameter of the tubules in SP animals was roughly less than half, meaning one eighth in volume compared to the LP animals.

\section{Histological examination of epididymides}

The histological views of the epididymis were generally associated to those of testes examined above (Fig. 6). The entire length of epididymides (caput, corpus, and caudal parts) of LP animals was filled with the sperm. But in the lumen of the epididymal tubules of SP animals, sperm were only observed in the caudal part of the epididymis. No sperm were witnessed in the caput and corpus parts of the epididymis. This finding was not expected.

The sperm observed in the epididymal tubules of animals housed in SP had the typical hooked 


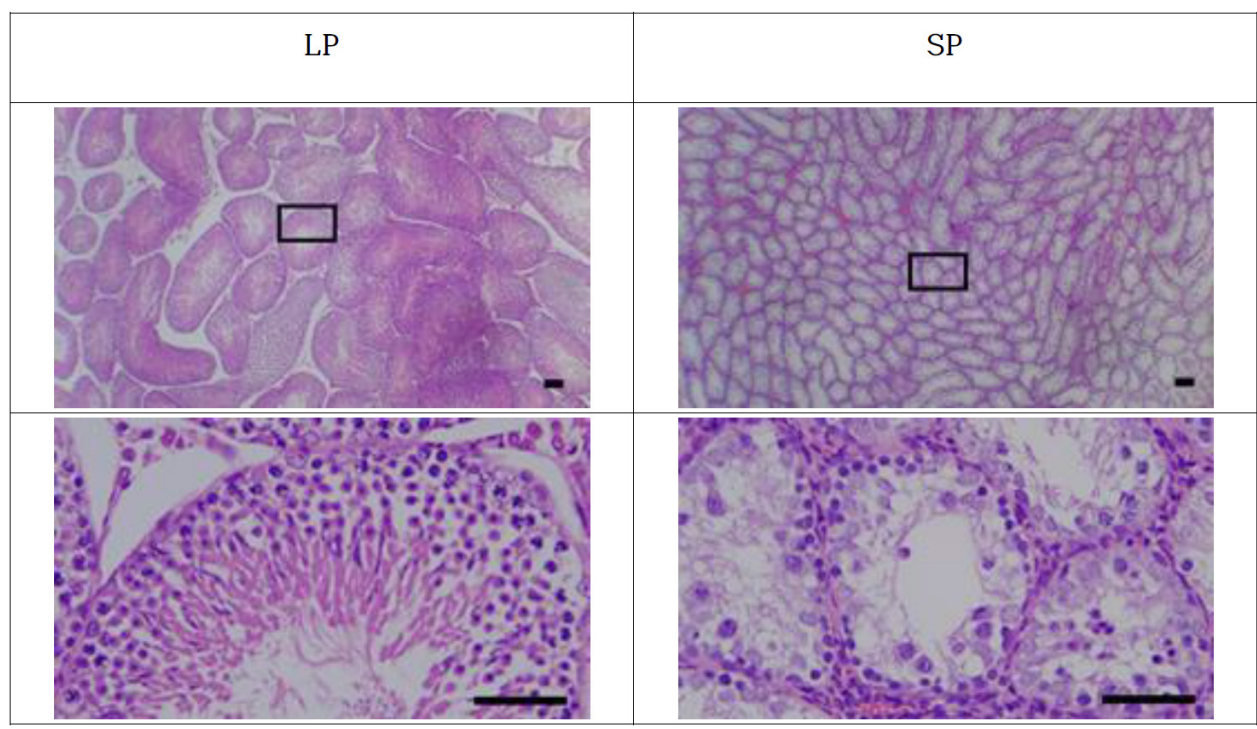

Fig. 5. Representative histological view of testis. The rectangles in upper row are amplified in lower row. Bar in upper row $=100 \mu \mathrm{m}$. Bar in lower row $=50 \mu \mathrm{m}$. LP, long photoperiod; SP, short photoperiod.

head shape of the normal sperm. Other round cells were observed as well, conjecturing as the germ cells and meaning cells detached from the epithelial tissue of both the seminiferous tubules of testicles and the epididymides. Those outcomes might denote the desquamation process of the germ cells in the process of regression by exposure to SP.

\section{DISCUSSION}

The exposure of Syrian hamsters to SP caused the testes to regress, as established by many previous investigations (Gaston \& Menaker, 1967; Elliott, 1976; Reiter, 1980; Stetson \& WatsonWhitmyre, 1984, 1986; Choi, 2013). The results of this investigation present the expressional aspects of BTB genes to be altered in the inactive testes. Also, many sperm were observed in the caudal region of the epididymis of hamster with the degenerated testes. To our knowledge, this is the first report that many sperm still were remained in the last regions of epididymis, meaning that all the germ cells are not engulfed through phagocytosis by Sertoli cells. Also, the outcome denotes that the sperm sloughed off the seminiferous tubules travel epididymis during the regressing course of the testes.

As well-known, SP induced complete regression of reproduction-related sex organs, affected the behavior to be a little sensitive to the touching, and had no influence on the weights of other various internal organs. The involution of the small testes was identified by the reduced weights of testes, epididymis, and seminal vesicles. And histological views showed no sperm in all the seminiferous tubules of the small testes. During the course of exposure to SP, the animals showed no significant difference of testicular masses in the 4 weeks of SP in comparison to the LP animals. The significant differences of testicular masses and weights were appeared in between LP and SP animals in the 8 weeks.

BTB is a well-organized cell membrane structure between Sertoli cells to regulate the transition of the germ cells. Three molecules related to components of BTB were examined in this experiment: claudin-11, occludin, and JAM. All of them are component proteins of the tight junctions those 


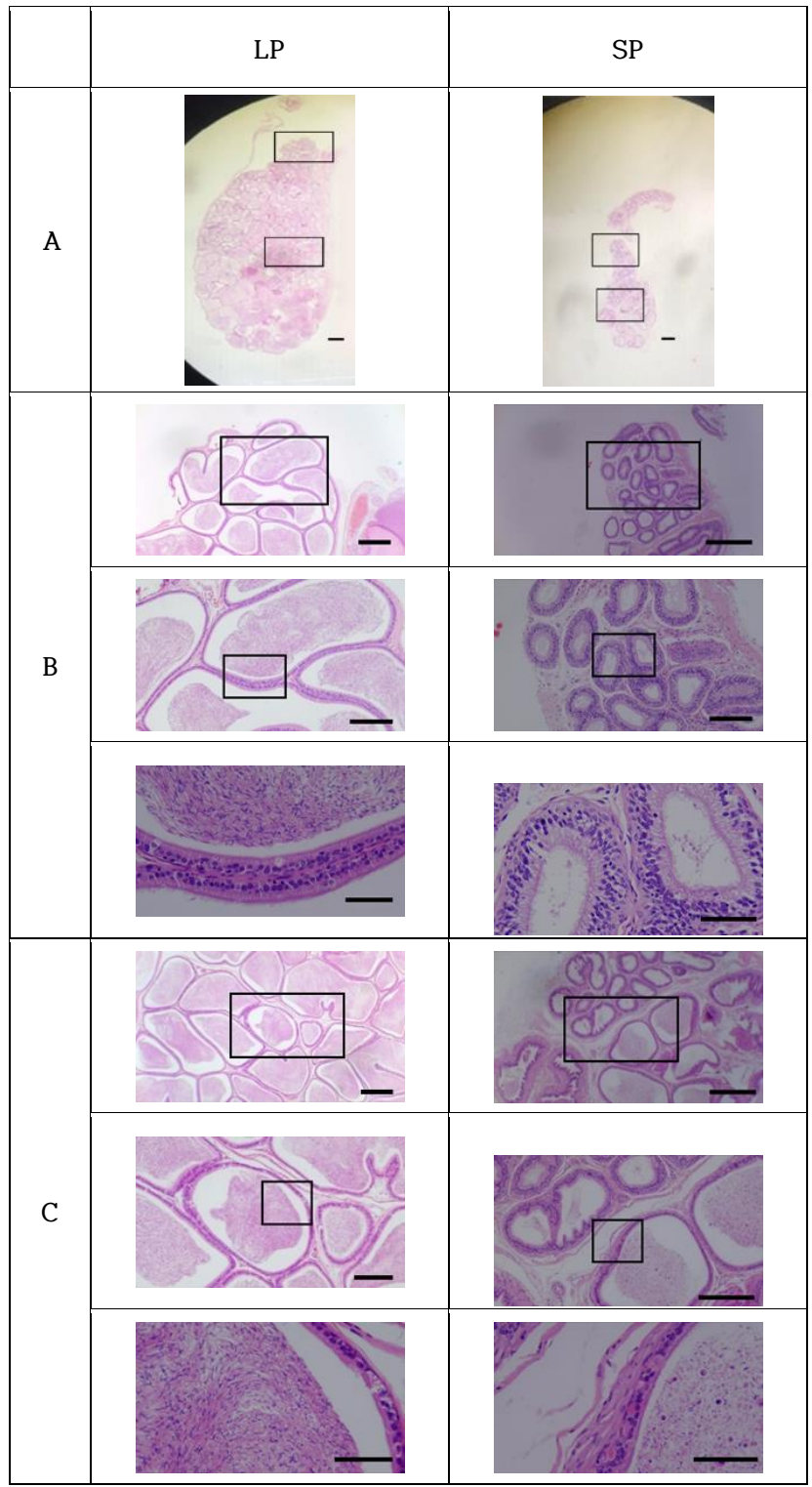

Fig. 6. Representative histological view of epididymis. A demonstrates the cauda epididymis. B presents the proximal part of cauda epididymis and $C$ the distal part of cauda epididymis. The upper and lower rectangles in $A$ are enlarged in $B$ and $C$, respectively. The rectangles of the top row in $B$ and $C$ are amplified in lower row. Scale bar in $A=2 \mathrm{~mm}$. Scale bar in top picture of $B$ and $C=1,000 \mu \mathrm{m}$. Scale bar in middle picture of $B$ and $C=500 \mu \mathrm{m}$. Scale bar in lower picture of $B$ and $C=125 \mu \mathrm{m}$. $\mathrm{LP}$, long photoperiod; SP, short photoperiod.

establish the paracellular barrier that controls the movement of germ cells in the intercellular space of Sertoli cells (Mruk \& Cheng, 2015; Merico et al., 2019).

In the present investigation, claudin-11 and occludin were strongly expressed in the reproductive active testes. JAM was weakly expressed. Thus, these molecules are considered to be associated with the movement of germ cells. On the other hand, in the inactive testes both claudin-11 and occludin were not detected at all and JAM was expressed barely detectably. The absence of the gene expressions observed in the regressed testes was accompanied by the absence of the maturing germ cells as well as sperm and indicated a sort of modification of tight junction, which are previously reported (Seco-Rovira et al., 2015). 
During the normal spermatogenesis, the initial preleptotene/leptotene cells pass through the space of adjacent Sertoli cells where the molecules composing of tight junction are reorganized by opening and closing (Cheng \& Mruk, 2012; Wen et al., 2018). Afterward they reach the adluminal compartment of the epithelium of seminiferous tubules, become spermatids, and transforms into the sperm by spermiogenesis those were abundant in the lumen. SP animals showed primarily spermatogonia at the basal laminar and some germ cells in the tubules, proposing still remaining of meiotic process. No spermatids and mature sperm were observed at all in the epithelium and the lumen of the tubules in the inactive testes. The general aspects observed in the inactive testes were associated with the lack of expressions of tight junction genes used in the present experiment, which implies the permeation of BTB (Munoz et al., 1997; Jiménez et al., 2015; Massoud et al., 2018). Although the cause and effect are not clear, it could be speculated that the disorganization of tight junction in the BTB structure loses and releases the germ cells. On the other hand, apoptosis was reported as a method to swallow the aberrant germ cells (Young et al., 1999, 2001; Morales et al., 2002, 2007; Smith et al., 2014; Seco-Rovira et al., 2015; Silva \& Barton, 2016). In the testes of Syrian hamsters undergoing testicular regression, the phagocytosis of the Sertoli cell might not be enough to scavenge the deviant cells. This notion is supported by the presence of sperm and round cells remained in the caudal epididymis.

The caudal region of epididymis in the reproductively inactive animals contained sperm but caput and corpus regions near to the testes had no sperm and any other types of cells at all. These unexpected results direct to the desquamation that is a possible procedure occurring in the epithelial layer of the seminiferous tubules in the regressing testes. Thus, it is reasonable to consider that in the regressing testes the germ cells developing in the epithelium begin to liberate from the Sertoli cells and flow to the lumen. During the initial phase some germ cells are engulfed into the Sertoli cells and the remained cells continue to travel the downstream of the reproductive tract. It is not possible from this investigation to determine the time when the germ cells start to release from the epithelium. The true effects of SP are speculated as the time that the structure of BTB begin to disorganize and then germ cells are detached from the epithelium of the seminiferous tubules. Once the germ cells enter the lumen, they should follow the downstream with apoptosis, if any, and recedes into the epididymis and vas deferens. The sperm witnessed in the last part of the epididymis could be the last batch of freed germ cells from the epithelium. The caudal region has a widened diameter and is a well-known space storing sperm (Zhou et al., 2018). The sperm might experience a bottleneck situation and delay the drainage receding into the vas deferens. They ultimately leave the epididymis for the vas deferens and out of body.

In conclusion, the present results imply that the disorganization of tight junction consisting of the BTB accompanies the testicular regression. The developing germ cells in the epithelium of seminiferous tubules are released from the Sertoli cells in the regressing testes. They are swallowed into the Sertoli cells by the phagocytosis or travel into the lumen, supported by the remained sperm in the last region of the epididymis. Accordingly, these findings suggest that apoptosis and desquamation are the processes that eliminate the germ cells in the course of regression in the Syrian hamsters. Further investigations are required to find which molecules are mainly involved and when the situations are occurred in the process of testicular regression.

\section{REFERENCES}

Andersen Berg K, Wiger R, Dahl E, Torp T, Farstad W, Krogenaes A, McNeilly AS, Paulenz H, Ropstad E (2001) Seasonal changes in spermatogenic activity and in plasma levels of FSH, LH 
and testosterone, and the effect of immunization against inhibin in the male silver fox (Vulpes vulpes). Int J Androl 24:284-294.

Cheng CY, Mruk DD (2012) The blood-testis barrier and its implications for male contraception. Pharmacol Rev 64:16-64.

Choi D (2013) Potency of melatonin in living beings. Dev Reprod 17:149-177.

Choi D, Lee SH (2012) Neuroendocrine system in seasonal breeder: Focusing on the reproductive activity of male golden hamster. Dev Reprod 16:1-8.

Dadhich RK, Barrionuevo FJ, Real FM, Lupiañez DG, Ortega E, Burgos M, Jiménez R (2013) Identification of live germ-cell desquamation as a major mechanism of seasonal testis regression in mammals: A study in the Iberian mole (Talpa occidentalis). Biol Reprod 88:101.

Dadhich RK, Real FM, Zurita F, Barrionuevo FJ, Burgos M, Jiménez R (2010) Role of apoptosis and cell proliferation in the testicular dynamics of seasonal breeding mammals: A study in the Iberian mole, Talpa occidentalis. Biol Reprod 83:83-91.

de Kretser DM, Loveland KL, Meinhardt A, Simorangkir D, Wreford N (1998) Spermatogenesis. Hum Reprod 13 Suppl 1:1-8.

Elliott JA (1976) Circadian rhythms and photoperiodic time measurement in mammals. Fed Proc 35:2339-2346.

Gaston S, Menaker M (1967) Photoperiodic control of hamster testis. Science 158:925-928.

Gliki G, Ebnet K, Aurrand-Lions M, Imhof BA, Adams RH (2004) Spermatid differentiation requires the assembly of a cell polarity complex downstream of junctional adhesion molecule-C. Nature. 431:320-324.

Hollenbach J, Jung K, Noelke J, Gasse H, Pfarrer C, Koy M, Brehm R (2018) Loss of connexin43 in murine Sertoli cells and its effect on blood-testis barrier formation and dynamics. PLOS ONE 13:e0198100.

Jeon GH, Kim HJ, Park J, Lee SH, Cheon YP, Choi D (2020) The effects of daily melatonin gavage on reproductive activity in the male Syrian hamsters. Dev Reprod 24:263-275.

Jiménez R, Burgos M, Barrionuevo FJ (2015) Circannual testis changes in seasonally breeding mammals. Sex Dev 9:205-215.

Lee JS, Oh HA, Kwon JY, Jeong MH, Lee JS, Kang DW, Choi D (2013) The effects of Cynomorium songaricum on the reproductive activity in male golden hamsters. Dev Reprod 17:37-43.

Luaces JP, Rossi LF, Merico V, Zuccotti M, Redi CA, Solari AJ, Merani MS, Garagna S (2013) Spermatogenesis is seasonal in the large hairy armadillo, Chaetophractus villosus (Dasypodidae, Xenarthra, Mammalia). Reprod Fertil Dev 25:547-557.

Luaces JP, Rossi LF, Sciurano RB, Rebuzzini P, Merico V, Zuccotti M, Merani MS, Garagna S (2014) Loss of Sertoli-germ cell adhesion determines the rapid germ cell elimination during the seasonal regression of the seminiferous epithelium of the large hairy armadillo Chaetophractus villosus. Biol Reprod 90:48.

Massoud D, Lao-Pérez M, Hurtado A, Abdo W, Palomino-Morales R, Carmona FD, Burgos M, Jiménez R, Barrionuevo FJ (2018) Germ cell desquamation-based testis regression in a seasonal breeder, the Egyptian long-eared hedgehog, Hemiechinus auritus. PLOS ONE 13:e0204851.

Mazaud Guittot S, Meugnier E, Pesenti S, Wu X, Vidal H, Gow A and Le Magueresse Battistoni B (2010) Claudin 11 deficiency in mice results in loss of the Sertoli cell epithelial phenotype in the testis. Biol Reprod 82:202 213.

Meng J, Holdcraft RW, Shima JE, Griswold MD, Braun RE (2005) Androgens regulate the permeability of the blood-testis barrier. Proc Natl Acad Sci USA 102:16696-16700.

Merico V, Luaces JP, Rossi LF, Rebuzzini P, Merani MS, Zuccotti M, Garagna S (2019) Sertoli- 
immature spermatids disengagement during testis regression in the armadillo. Reproduction 157:27-42.

Morales E, Ferrer C, Zuasti A, Garcia-Borron JC, Canteras M, Pastor LM (2007) Apoptosis and molecular pathways in the seminiferous epithelium of aged and photoinhibited Syrian hamsters (Mesocricetus auratus).J Androl 28:123-135.

Morales E, Pastor LM, Ferrer C, Zuasti A, Pallares J, Horn R, Calvo A, Santamaria L, Canteras M (2002) Proliferation and apoptosis in the seminiferous epithelium of photoinhibited Syrian hamsters (Mesocricetus auratus). Int J Androl 25:281-287.

Morita K, Sasaki H, Fujimoto K, Furuse M, Tsukita S (1999) Claudin 11/OSP based tight junctions of myelin sheaths in brain and Sertoli cells in testis.J Cell Biol 145:579 588.

Morrow CMK, Tyagi G, Simon L, Carnes K, Murphy KM, Cooke PS, Hofmann MC, Hess RA (2009) Claudin 5 expression in mouse seminiferous epithelium is dependent upon the transcription factor ets variant 5 and contributes to blood-testis barrier function. Biol Reprod 81:871-879.

Mruk DD, Cheng CY (2015) The mammalian blood-testis barrier: Its biology and regulation. Endocr Rev 36:564-591.

Muñoz E, Fogal T, Dominguez S, Scardapane L, Guzman J, Piezzi RS (1997) Seasonal changes of the Leydig cells of viscacha (Lagostomus maximus maximus). A light and electron microscopy study. Tissue Cell 29:119-128.

Pan J, Zhu Z, Xu G, Niu L, Yu L, Luo Z, Yan J (2018) Expression of claudin 11 in a rat model of varicocele and its effects on the blood testis barrier. Mol Med Rep 18:5647-5651.

Reiter RJ (1980) The pineal and its hormones in the control of reproduction in mammals. Endocr Rev 1:109-131.

Saitou M, Furuse M, Sasaki H, Schulzke JD, Fromm M, Takano H, Noda T, Tsukita S (2000) Complex phenotype of mice lacking occludin, a component of tight junction strands. Mol Biol Cell 11:4131-4142.

Seco-Rovira V, Beltrán-Frutos E, Ferrer C, Saez FJ, Madrid JF, Canteras M, Pastor LM (2015) Testicular histomorphometry and the proliferative and apoptotic activities of the seminiferous epithelium in Syrian hamster (Mesocricetus auratus) during regression owing to short photoperiod. Andrology 3:598-610.

Silva ND, Barton CR (2016) Macrophages and dendritic cells in the post-testicular environment. Cell Tissue Res 363:97-104.

Smith TB, Cortez-Retamozo V, Grigoryeva LS, Hill E, Pittet MJ, Da Silva N (2014) Mononuclear phagocytes rapidly clear apoptotic epithelial cells in the proximal epididymis. Andrology 2:755-762.

Stetson MH, Watson-Whitmyre M (1984) Physiology of the pineal and its hormone melatonin in annual reproduction in rodents. In: Reiter RJ (ed), The Pineal Gland. Raven Press, New York, NY, pp 109-153.

Stetson MH, Watson-Whitmyre M (1986) Effects of exogenous and endogenous melatonin on gonadal function in hamsters. J Neural Transm 21:S55-S80.

Watson-Whitmyre M, Stetson MH (1985) A mathematical method for estimating paired testes weight from in situ testicular measurements in three species of hamster. Anat Rec 213:473-476.

Wen Q,Tang EI, Li N, Mruk DD, Lee WM, Silvestrini B, Cheng CY (2018) Regulation of bloodtestis barrier (BTB) dynamics, role of actin-, and microtubule-based cytoskeletons. Methods Mol Biol 1748:229-243.

Young KA, Ball GF, Nelson RJ (2001) Photoperiod-induced testicular apoptosis in European starlings (Sturnus vulgaris). Biol Reprod 64:706-713. 
Young KA, Zirkin BR, Nelson RJ (1999) Short photoperiods evoke testicular apoptosis in whitefooted mice (Peromyscus leucopus). Endocrinology 140:3133-3139.

Zhou W, De Iuliis GN, Dun MD, Nixon B (2018) Characteristics of the epididymal luminal environment responsible for sperm maturation and storage. Front Endocrinol 9:59. 